\title{
Community-Based Medical Student Nutrition Counseling Training for Low-Income Families
}

Amy S. Williams, MD, MSPH | Pooja M. Patel, MD, MHA, BDS | Nathan L. Beucke, MD | Richelle J. Koopman, MD, MS

Published: 2/12/2018 | DOI: 10.22454/PRiMER.2018.809708

\section{Abstract}

Background and Objectives: Physician nutrition counseling has become increasingly important due to increases in child and adult obesity. However, medical student education on nutrition counseling, especially for low-income families, is insufficient.

Methods: Eat Healthy, Stay Active! (EHSA) is a community-based child obesity program that provided experiential learning for medical students to counsel low-income Head Start families about nutrition. The authors conducted a focus group to explore medical students' opinions about the proficiency of their nutrition education skills, especially in low-income families, and the role of EHSA. The authors also surveyed students about their self-confidence in providing low-income families with nutrition counseling.

Results: Most students reported a favorable overall impression of EHSA with a mean score of 7 on a 10-point scale ( $1=$ poor experience, $10=$ very positive experience) and $70 \%$ reporting they would recommend EHSA to their classmates. They also reported a significant $(80 \%, P<0.0001)$ increase in their confidence of counseling patients about child obesity after participating in EHSA. In focus groups, students felt that EHSA improved their nutrition knowledge and helped them to understand barriers of low-income families for healthy nutrition.

Conclusions: Students participating in EHSA, a novel, community-based, experiential learning project, gained self-confidence in providing nutrition counseling to low-income families. The program also positively impacted medical student personal opinions of low-income families by providing a personal reference for low-income struggles.

\section{Introduction}

Physician nutrition counseling is important for the prevention and treatment of obesity-related diseases. ${ }^{1}$

Unfortunately, current nutrition education in medical schools does not adequately prepare future physicians for this role. ${ }^{2}$ Despite the obesity epidemic, dedicated teaching time and student interest in nutrition has declined. ${ }^{2}$ In 2009 only $27 \%$ of medical schools met the National Academy of Science recommendations for a minimum of 25 hours of nutrition education, compared to $38 \%$ of schools in $2004 .{ }^{3}$ Many young doctors enter practice with no practical experience educating low-income families on health behavior. ${ }^{4}$ Experiential learning through community-based projects provides a novel approach to teaching through transformative experiences outside of a traditional medical school curriculum. ${ }^{5}$ One such program we studied was Eat Healthy, Stay Active! (EHSA).

EHSA was designed at the HealthCare Institute at the University of California-Los Angeles in 2008 as a multilevel obesity prevention program that includes Head Start children, parents, and staff. ${ }^{6}$ EHSA was piloted in the MidMissouri area via the Central Missouri Community Action Council (CMCA) and Head Start in several central Missouri counties in 2012. In 2013, EHSA began to include first and second-year medical students who volunteered to 
participate as instructors and family coaches in the extracurricular program at the University of Missouri. The multilevel approach of EHSA includes curriculum in the classrooms to teach basic healthy nutrition and activities to Head Start children and programs for Head Start staff to achieve healthy weights. Parents receive educational sessions, some of which were led by medical students, to teach budget-conscious healthy weight practices for their families. Before the program begins in the community, medical students also receive training about the cultural implications of poverty, nutrition in the low-income populations, and health literacy. Medical students were also paired with families and encouraged to do home and Head Start site visits to increase interaction-based experiential learning opportunities with families and students. They provided personalized counseling with families regarding nutrition and exercise (see Table 1 for a description of EHSA student activities). We evaluated the role of this community-based experiential learning program to teach nutrition counseling skills to medical students working with low-income families.

\section{Methods}

We surveyed medical students who participated in EHSA and conducted a student focus group composed of a subgroup of volunteers. Because EHSA is designed to help Head Start staff and families improve their lifestyle habits, it is both an obesity prevention program for those who aren't obese, and a treatment program for those who are. Focus group participants provided informed consent and received compensation of $\$ 20$ cash. The principal author (ASW) and a coauthor (PMP) moderated the 60-minute session using a semistructured script; a third author (RJK) observed. To try to reduce risk of bias, none of the focus group facilitators were EHSA faculty. All students who participated in EHSA were asked to complete either an online or paper survey, consisting of nine questions (Table 2; an EHSA medical student emailed survey). We compared the results from surveys using a paired $t$-test of binomial proportions.

We asked the focus group participants their overall views on nutrition education and experiences with EHSA. The focus group session was audio recorded and then transcribed by a qualitative transcriptionist. Using Dedoose qualitative software, the resulting transcript was analyzed independently by authors ASW, PMP, and RJK using thematic analysis. Quantitative data were analyzed using descriptive statistics, and chi-square test. The University of Missouri Health Sciences Institutional Review Board approved this project.

\section{Results}

A total of 13 students participated in EHSA in academic year 2013-2014, and 22 students in academic year 2014-2015. Between both groups, 20 completed the survey (63\% response rate) and five of these students participated in a focus group in August of 2015. The focus group included five medical students aged 20 to 30 . Four participants were female and one was male. At the time of the focus group, one participant was in the fourth year of medical school, one in the second year, and the rest were third-year students.

Results showed that most students participated in EHSA because they wanted to learn about childhood obesity or work with low-income families ( $80 \%$ and $90 \%$ respectively). Only $30 \%$ reported participating to learn about nutrition. Most students rated their overall experience with EHSA as positive with an average of 7 on a 10-point scale (1=poor experience, $10=$ very positive experience), and $70 \%$ reported that they were likely to recommend EHSA to other students. After participation in EHSA, $85 \%$ of students felt confident communicating about nutrition to their patients ( 7 or greater on a 10-point scale, with 1 being not confident at all and 10 being very confident; Table 2). Confidence in discussing childhood obesity (7 or greater on the same 10-point scale) also significantly increased from $5 \%$ before participating in EHSA to $85 \%$ after $(P<0.0001)$. Because students were only surveyed once after EHSA, they were asked to consider their confidence before and after EHSA.

Several themes were identified from the transcript of the focus group, including: (1) students felt that nutrition and behavior counseling education in medical school was not sufficient; (2) EHSA helped alleviate these deficits, (3) students' experiences with low-income families helped them understand the struggles and communicate more effectively with these families, and (4) they preferred experiential learning projects such as EHSA to traditional 


\section{Discussion}

Participation in EHSA provided a positive educational experience in several domains. Students reported that after participating in EHSA they were more confident in communicating with parents about nutrition (Theme 2), and there was an $80 \%$ increase in confidence about communicating about obesity to patients after EHSA compared to before.

EHSA also helped students build empathy toward low-income families by sharing their lived experiences (Theme 3 ) and helping them communicate with low-income families (Theme 4). Through their interactions at the classes and home visits, students began to understand the barriers of low-income families preventing them from following healthier lifestyles.

There was general agreement among the focus group students that nutrition education in medical school curriculum is inadequate (Theme 1). This was consistent with the dearth of medical school nutrition education reported in the literature nationally. ${ }^{3}$ Current nutrition education at the University of Missouri, School of Medicine includes about 2 hours of nutrition lectures and various topics integrated into the problem-based learning curriculum. Interactive, experiential learning projects such as EHSA can help. Students reported applying practical skills of discussing weight and nutrition through EHSA.

Although students in our study expressed a preference for experiential learning (Theme 5), it is our experience that formalized experiential learning opportunities such as EHSA in preclinical years are rare in traditional medical school curriculum. Medical school is a time for significant personal growth. Beyond growth in knowledge, students also develop core values and beliefs. In addition to choosing a specialty, students make important decisions regarding the patient population they want to serve and how they will practice. By providing students with transformative experiences through EHSA, students in our study formed a more favorable view of low-income families (Theme 3). Experiential learning has previously proven beneficial in improving medical student's knowledge and changing their attitudes toward low-income patients. ${ }^{5}$

Limitations of our study include being conducted at a single institution with a limited number of medical students in one focus group. The results from this study could be influenced greatly by small sample size. Additionally, results could be influenced by selection bias because participation in EHSA and in the survey and focus groups was voluntary. Finally, the validity of our study would improve if we had surveyed students before and after EHSA, rather than asking them to recall their confidence in communication skills retrospectively. Next steps include studying EHSA at other medical schools. More research is needed to understand if students who participate in experiential learning programs like EHSA learn, retain, and apply nutrition education over time. Further research is also needed to understand how to optimize experiential learning programs for behavior change counseling for medical students.

\section{Tables and Figures}


Table 1: EHSA Medical Student Experience

\begin{tabular}{|l|c|c|}
\hline \multicolumn{1}{|c|}{ Activity } & Time & Personnel/Resources \\
\hline $\begin{array}{l}\text { Medical Student Didactics: } \\
\text { - Head Start 101/Intro to EHSA! } \\
\text { - Understanding Health Literacy } \\
\text { - Health and Nutrition }\end{array}$ & 1 to 2-hour lectures in the evening & $\begin{array}{l}\text { Facilitated by Head Start staff and Health } \\
\text { Literacy Missouri with input from volunteer } \\
\text { faculty advisor. } \\
\text { Newest Vital Sign-Health Literacy Tool }\end{array}$ \\
\hline $\begin{array}{l}\text { Parent training } \\
\text { Goal setting with family }\end{array}$ & Three 2-hour sessions in the evening & $\begin{array}{c}\text { EHSA! Curriculum developed by UCLA } \\
\text { Health Care Institute }\end{array}$ \\
\hline Home visit with Head Start family & 1-hour session & None \\
\hline Classroom visit at Head Start facility & Three 2-hour session & Head Start teachers \\
\hline Journaling of experiences & 2 hours & None \\
\hline Success celebration with families & 2 hours & \\
\hline
\end{tabular}

*Total time commitment: 25 hours over the 5-month period

Table 2: EHSA Medical Student Survey

\begin{tabular}{|c|c|c|}
\hline & Question & Answers \\
\hline 1 & $\begin{array}{l}\text { Why did you choose to participant } \\
\text { in Eat Healthy, Stay Active? (choose } \\
\text { all that apply) }\end{array}$ & $\begin{array}{l}\text { 1. I wanted to learn more about childhood obesity } \\
\text { 2. I wanted to learn more about nutrition } \\
\text { 3. I wanted to learn more about health care in low-income families } \\
\text { 4. I wanted to learn more about health literacy } \\
\text { 5. special designation on the Dean's letter } \\
\text { 6. I wanted to work with low-income families and children } \\
\text { 7. I am interested in the culture of poverty } \\
\text { 8. others: }\end{array}$ \\
\hline 2 & $\begin{array}{l}\text { On a scale of } 1-10 \text {, please rate your } \\
\text { overall experience with Eat Healthy, } \\
\text { Stay Active. }\end{array}$ & Numeric $1-10$ ( 1 being poor experience, 10 being very positive experience) \\
\hline 3 & $\begin{array}{l}\text { On a scale of } 1-5, \text { please rate your } \\
\text { educational experience with the } \\
\text { following areas: } \\
\text { medical student training sessions } \\
\text { parent education sessions } \\
\text { Head Start site visit }\end{array}$ & Numeric $1-5$ ( 1 being poor experience, 5 being very positive experience) \\
\hline 4 & $\begin{array}{l}\text { On a scale of } 1-10 \text {, how confident } \\
\text { do you feel communicating about } \\
\text { nutrition to your patients or peers. }\end{array}$ & Numeric $1-10$ ( 1 being not confident at all and 10 being very confident) \\
\hline 5 & $\begin{array}{l}\text { Before participating in Eat Healthy, } \\
\text { Stay Active On a scale of } 1-10 \\
\text { how comfortable were you } \\
\text { communicating with parents about } \\
\text { obesity in his or her child? }\end{array}$ & Numeric $1-10$ ( 1 being not confident at all and 10 being very confident) \\
\hline 6 & $\begin{array}{l}\text { After participating in Eat Healthy, } \\
\text { Stay Active, on a scale of } 1-10 \text { how } \\
\text { comfortable are you communicating } \\
\text { with parents about obesity in his or } \\
\text { her child? }\end{array}$ & Numeric $1-10$ ( 1 being not confident at all and 10 being very confident) \\
\hline 7 & $\begin{array}{l}\text { Do you feel that the time } \\
\text { commitment to participant in Eat } \\
\text { Healthy, Stay Active was: }\end{array}$ & $\begin{array}{l}\text { 1. too much time? } \\
\text { 2. just right time? } \\
\text { 3. not enough time? }\end{array}$ \\
\hline 8 & $\begin{array}{l}\text { How likely are you to recommend } \\
\text { participating in Eat Healthy, Stay } \\
\text { Active! to other medical students? }\end{array}$ & $\begin{array}{l}\text { 1. Not likely at all } \\
\text { 2. Maybe likely } \\
\text { 3. Very likely }\end{array}$ \\
\hline 9 & $\begin{array}{l}\text { What additional comments or } \\
\text { suggestions do you have for } \\
\text { improving the program? }\end{array}$ & [This field was available for write-in answers] \\
\hline
\end{tabular}


Table 3: EHSA Focus Group Results

\begin{tabular}{|c|c|}
\hline Theme & Quote \\
\hline $\begin{array}{l}\text { Nutrition and behavior counseling education } \\
\text { in medical school is insufficient }\end{array}$ & $\begin{array}{l}\text { "We didn't get training about how to counsel people in nutrition. No. We don't." } \\
\text { "I do remember giving one lecture on behavior change, in behavior modification } \\
\text { lectures. That was kind of (it), and they did mention that nutrition counseling could be } \\
\text { used in that manner." } \\
\text { "Yeah, but that was more for adults that are motivated to learn so you're addressing } \\
\text { the adult on how do you think you can change, what is your motivation to change, but } \\
\text { kids, it's a little bit different" }\end{array}$ \\
\hline $\begin{array}{l}\text { EHSA helps alleviate nutrition education } \\
\text { deficits }\end{array}$ & $\begin{array}{l}\text { "I felt like I was a little more confident wading into that conversation than I was before. } \\
\text { I actually had something to give them other than "By the way, your child is..." since } \\
\text { I had a little bit of the information from the My Plate and stuff for them to actually } \\
\text { follow." } \\
\text { "At the time that I did the Eat Healthy, Stay Active, I didn't actually think very much } \\
\text { of it, and it wasn't until a year later when I was doing pediatrics in } * * * * \\
\text { had to tell a parent "No, your three-year-old should not be that weight," that (I) kind } \\
\text { of realized how much I did learn about how to talk to patients and families about } \\
\text { nutrition-type stuff." }\end{array}$ \\
\hline $\begin{array}{l}\text { Interacting with low-income families helped } \\
\text { students to understand their struggles and } \\
\text { lived experience }\end{array}$ & $\begin{array}{l}\text { "Especially if you're a lower income (parent), and you don't have a lot of the available } \\
\text { resources. That was sort of a, it was fun to actually sit there and talk and say "Run } \\
\text { me through your normal day." "OK, I work until } 7: 00 \text {, I'm tired, the easiest thing to do } \\
\text { is to go out and just buy McDonald's or fried chicken." } \\
\text { "I think for me, the most I got out of it was actually learning about all the services } \\
\text { that Head Start provides, and how intricately they're involved in the community with } \\
\text { families that are low-income and that are struggling." }\end{array}$ \\
\hline $\begin{array}{l}\text { EHSA helped students learn how to } \\
\text { effectively communicate with low-income } \\
\text { families }\end{array}$ & $\begin{array}{l}\text { ".... we don't fully realize how big of a gap there is sometimes, and how things that } \\
\text { we know are healthy, or know that aren't healthy, people have no clue, and that's just } \\
\text { what they know. Which is fine, but it charges us with more of a responsibility to make } \\
\text { sure that when we check our box of "Oh, yeah, I covered nutrition," did we actually } \\
\text { assess what they know and how functional they are in making healthy choices, } \\
\text { because I think that we don't always appreciate that as much as we should. } \\
\text { We say diet and exercise, but we don't truly know what any of those mean." } \\
\text { "It's a good way for us to take people who think they have no resources and show } \\
\text { them the resources that they do have to make healthy changes. They say "'m } \\
\text { tired, and I can't afford to go buy expensive food." "Well, here are some alternatives } \\
\text { that are healthy. Here are some ways to coupon and to get those healthy things or } \\
\text { something that you can afford" } \\
\text { "I think the coolest thing was exploring about the different food, because we always } \\
\text { tell people about they need to change their diet, but we don't really know what we } \\
\text { can do to change that so the healthy living books and the training the parents did, I } \\
\text { thought that was really helpful." }\end{array}$ \\
\hline $\begin{array}{l}\text { Students prefer experiential learning } \\
\text { projects such as EHSA to traditional } \\
\text { learning }\end{array}$ & $\begin{array}{l}\text { "I'm always going to go with experiential over classroom based. I mean, when the first } \\
\text { little kid latches on to your leg, you're pretty much sold for that, it gives you a drive } \\
\text { and motivation and actually seeing that you're making a difference or at least working } \\
\text { on that, developing those skills is a very viable experience to have." } \\
\text { "And that's the frustrating part, they're not teaching us enough of the practical } \\
\text { doctoring skills. If I were to take anything out of it, I think l'd put learning from } \\
\text { experience is definitely one of them" }\end{array}$ \\
\hline
\end{tabular}

\section{Acknowledgments}

The authors would like to acknowledge Drs Carol Tuetsch, Ariella Herman, and Bergen Nelson at UCLA for their creation of EHSA, and Mernell King and Jackie Rivera at Central Missouri Community Action for their implementation of local EHSA.

Financial support:This project was supported by grant number R24HS022140 from the Agency for Healthcare Research and Quality. The content is solely the responsibility of the authors and does not necessarily represent the official views of the Agency for Healthcare Research and Quality.

\section{Presentations:}


1. Williams A, Patel P, Beucke N, Koopman, R. Community-Based Training to Enhance Medical Student Educations in Areas of Nutrition counseling, Health Literacy, and Poverty, poster at STFM Annual Spring Conference, Minneapolis, MN, May 2, 2016.

2. Patel P, Wasserman M, Koopman R, Williams A. Evaluating the Efficacy and Long-term Sustainability of the Eat Healthy, Stay Active! Program: a Qualitative Study, poster presented at STFM Annual Spring Conference, Orlando, FL, April 28, 2015.

\section{Corresponding Author}

Amy S. Williams, MD, MSPH

Curtis W. and Ann H. Long Department of Family and Community Medicine, University of Missouri, 7 Hospital Drive, MA 306, Columbia, MO 65201. 573-882-2190. Fax: 573-884-6172

williamsamy@health.missouri.edu

\section{Author Affiliations}

Amy S. Williams, MD, MSPH - Department of Family and Community Medicine, University of Missouri in Columbia, MO

Pooja M. Patel, MD, MHA, BDS - Providence St. Peter Hospital, University of Washington in Olympia, WA Nathan L. Beucke, MD - Department of Child Health, University of Missouri School of Medicine, Columbia, MO Richelle J. Koopman, MD, MS - Department of Family and Community Medicine, University of Missouri, Columbia, MO

\section{References}

1. Rees K, Dyakova M, Wilson N, Ward K, Thorogood M, Brunner E. Dietary advice for reducing cardiovascular risk. Cochrane Database Syst Rev. 2013;12:CD002128.

2. Frantz DJ, Munroe C, McClave SA, Martindale R. Current perception of nutrition education in U.S. medical schools. Curr Gastroenterol Rep. 2011;13(4):376-379. https://doi.org/10.1007/s11894-011-0202-z.

3. Adams KM, Kohlmeier M, Zeisel SH. Nutrition education in U.S. medical schools: latest update of a national survey. Acad Med. 2010;85(9):1537-1542. https://doi.org/10.1097/ACM.0b013e3181eab71b.

4. Satterfield J, Carney P. Aligning medical education with the nation's health priorities: innovations in physician training in behavioral and social sciences. AHRQ Population Health: Behavioral and Social Science Insights. http://www.ahrq.gov/professionals/education/curriculum-tools/population-health/satterfield.html. Published September, 2015. Accessed May 17, 2016.

5. Friedland AR, Rintel-Queller HC, Unnikrishnan D, Paul DA. Field trips as a novel means of experiential learning in ambulatory pediatrics. J Grad Med Educ. 2012;4(2):246-249.

https://doi.org/10.4300/JGME-D-11-00173.1.

6. Herman A, Nelson BB, Teutsch C, Chung PJ. "Eat Healthy, Stay Active!": a coordinated intervention to improve nutrition and physical activity among Head Start parents, staff, and children. Am J Health Promot.

2012;27(1):e27-e36. https://doi.org/10.4278/ajhp.110412-QUAN-157.

Copyright $@ 2018$ by the Society of Teachers of Family Medicine 